\title{
SANITASI TOTAL BERBASIS MASYARAKAT (STBM) DI DESA MUARA PUTIH KECAMATAN NATAR KABUPATEN LAMPUNG SELATAN
}

\author{
Prayudhy Yushananta $^{1}$, Mei Ahyanti ${ }^{*}$, Amrul Hasan ${ }^{1}$ \\ ${ }^{I}$ Dosen Jurusan Kesehatan Lingkungan Poltekkes Tanjungkarang \\ Jl. Raya Hajimena KM. 14 No. 100 Natar Lampung Selatan \\ Penulis Korespodensi : mei.ahyanti@gmail.com
}

\begin{abstract}
Abstrak
Sanitasi merupakan kunci kesehatan. Karena sanitasi yang buruk adalah penyebab terbesar kedua timbulnya penyakit di dunia ini. Banyak faktor yang secara langsung maupun tidak langsung dapat menjadi pendorong terjadinya diare. Desa Muara Putih berada di Kecamatan Natar Kabupaten Lampung Selatan merupakan desa yang ditetapkan sebagai desa ODF sementara 629 KK belum memiliki jamban. Desa Muara Putih memiliki 6 dusun, yaitu Dusun Muara Putih Induk, Mujimulyo, Tangkit Batu, Way Kandis, Cisarua dan Sidomukti. Diantara 6 dusun tersebut tingkat kepemilikian jamban terendah adalah Dusun Mujimulyo. Selama ini, warganya masih banyak yang melakukan pembuangan tinja dan air limbah domestik langsung ke dalam aliran air yang ada di desa tersebut. Kegiatan bertujuan meningkatkan derajat kesehatan masyarakat melalui instalasi WC percontohan secara swadaya dan perubahan prilaku melalui penyuluhan. kegiatan yang dilaksanakan meliputi pemetaan, pemicuan kepada masyarakat, musyawarah masyarakat desa (MMD) dan pembangunan sarana jamban keluarga, penyuluhan ISPA, Diare, CTPS dan Kecacingan. Sebanyak 5 jamban telah terbangun selama periode kegiatan.
\end{abstract}

Kata kunci: Diare, Muara Putih, ODF, Sanitasi

\section{Pendahuluan}

Sanitasi merupakan kunci kesehatan. Karena sanitasi yang buruk adalah penyebab terbesar kedua timbulnya penyakit di dunia ini. Bank Dunia mencatat bahwa penyakit akibat sanitasi yang tidak layak di Indonesia pada tahun 2008 mencapai 56 triliun. Bahkan, 120 juta penduduk Indonesia dilaporkan terserang penyakit diare per tahunnya ${ }^{[1]}$. Di lain pihak, hasil studi organisasi kesehatan dunia (WHO) menunjukkan bahwa dengan sanitasi yang baik, terutama dalam lingkungan rumah tangga, dapat menurunkan 94 persen kasus diare. Menurunnya kasus diare amat berpengaruh dalam meningkatkan produktivitas dan juga taraf hidup masyarakat. Hal ini menunjukkan bahwa sanitasi yang baik memang merupakan salah satu persyaratan mutlak bagi terciptanya hidup sehat dan berkualitas.

Sanitasi yang kurang baik dapat menyebabkan penyakit menular. Penyakit menular merupakan problema yang cukup besar di negara sedang berkembang dan menyebabkan angka kesakitan dan kematian yang cukup tinggi. Salah satu dari penyakit menular itu adalah diare. Diare merupakan suatu kondisi dimana seseorang buang air besar 3 kali atau lebih dalam satu hari dan tinja atau faeses yang keluar berupa cairan encer atau sedikit berampas, kadang juga disertai darah atau lendir. Sampai saat ini penyakit diare masih merupakan salah satu masalah kesehatan utama bagi masyarakat di Indonesia. Dari daftar urutan penyebab kunjungan Puskesmas, hampir selalu termasuk dalam kelompok 3 penyebab utama bagi masyarakat yang berkunjung ke puskesmas. Angka kesakitannya adalah sekitar 200 - 400 kejadian diare di antara 1000 penduduk setiap tahunnya. Dengan demikian di Indonesia dapat ditemukan penderita diare sekitar 60 juta kejadian setiap tahunnya, sebagian besar $(70-80 \%)$ dari penderita ini adalah anak-anak ( \pm 40 juta kejadian). Kelompok ini setiap tahunnya mengalami lebih dari satu kejadian diare. Sebagian dari penderita (1-2 \%) akan jatuh ke dalam dehidrasi dan kalau tidak segera ditolong 50- 60\% diantaranya dapat meninggal. Hal inilah yang menyebabkan sejumlah 350.000 - 500.000 anak meninggal setiap tahunnya. 
Penyakit Diare merupakan masalah global yang menjadi penyebab kematian pada anak nomor dua setelah pneumonia. Berdasarkan data, hampir sembilan juta anak usia di bawah lima tahun meninggal setiap tahun akibat penyakit ini. Kebanyakan orang yang meninggal akibat diare disebabkan oleh dehidrasi berat dan kehilangan cairan. Diare sering dikaitkan dengan infeksi gastrointestinal (saluran cerna), yang dapat disebabkan oleh berbagai macam organisme seperti bakteri, virus dan parasit. Mikrorganisme tersebut menyebar melalui makanan atau minuman yang terkontaminasi, atau bisa juga dari orang ke orang sebagai akibat dari kebersihan yang buruk, misalnya tidak cuci tangan sebelum memegang makanan atau makan tanpa cuci tangan terlebih dahulu.

Banyak faktor yang secara langsung maupun tidak langsung dapat menjadi faktor pendorong terjadinya diare, terdiri dari faktor pejamu, agen lingkungan dan perilaku. Faktor pejamu yang menyebabkan meningkatnya kerentanan terhadap diare, diantaranya tidak memberikan, kurang gizi, penyakit campak, dan imunodefisiensi.

Lingkungan yang tidak sehat menjadi salah satu faktor yang menyebabkan terjadinya diare. Perilaku hidup masyarakat kurang sesuai dengan norma hidup sehat, sehingga lingkungannya menjadi tercemar yang akhirnya dapat menimbulkan pengaruh buruk terhadap kesehatan manusia. Masyarakat yang membuang tinja sembarangan dilingkungan, dapat mencemari tanah dan air tanah yang akhirnya akan mempengaruhi kesehatan manusia. Tinja juga dapat merupakan sumber penularan penyakit pada manusia, terutama penyakit saluran pencernaan, salah satunya penyakit diare. Kebiasaan tidak mencucitangan dengan air sabun sebelum makan dan menggunakan air yang kotor untuk kebutuhan sehari-hari dapat mendukung terjadinya diare. Pelayanan sanitasi yang memadai, penyediaan air yang aman, pembuangan tinja yang sehat, sistem pembuangan sampah yang baik serta pendidikan hygiene dapat menekan tingkat kematian akibat Diare.

Dengan bertambah padatnya jumlah penduduk setiap tahun, maka tingkat aktivitas manusia meningkat dalam usaha untuk meningkatkan taraf hidup dan kesejahteraannya. Komponen penting dalam menunjang setiap aktivitas manusia adalah air. Air sangat dibutuhkan oleh manusia untuk proses metabolisme tubuh, juga untuk melakukan berbagai proses dalam kegiatannya. Salah satunya adalah kegiatan dalam proses rumah tangga dan industri. Semakin bertambahnya jumlah perumahan dan perkampungan yang mendiami satu area lingkungan, semakin berat pula lingkungan tersebut untuk menetralisir air limbah yang sebagian besar dihasilkan dari sisa penggunaan air bersih. Di Indonesia, air limbah pada umumnya langsung dibuang ke badan sungai tanpa dilakukan pengolahan (treatment) terlebih dahulu. Hal tersebut mengancam kelestarian lingkungan, karena keterbatasan kemampuan lingkungan untuk membersihkan dari pencemar (self purification) $\mathrm{m}$ elalui proses kimia-fisik-biologi yang berjalan secara alami di dalam badan air. Akibatnya sungai yang berfungsi sebagai salah satu sumber air bersih, dapat membawa berbagai penyakit (vehicle) yang membahayakan kesehatan manusia, disertai dengan menurunnya kualitas lingkungan seperti penurunan kualitas air, tanah, dan udara, sehingga stabilitas lingkungan terganggu.

Angka Kejadian Diare di Kabupaten Lampung Selatan tahun 2015 diperkirakan 21.034 jiwa $^{[2]}$. Selain Diare, permasalahan penyakit menular berbasis lingkungan yang sering muncul di masyarakat Indonesia adalah Infeksi Saluran Pernafasan Akut (ISPA) dan kecacingan. Berdasarkan survey kematian balita, tahun 2012 masih sebanyak 40 per $1.000 \mathrm{KH}{ }^{[3]}$ Tahun 2015, target sasaran penemuan Pneumonia sebanyak $10 \%$ dari penemuan ISPA. Di Tanjungsari Kecamatan Natar Kabupaten Lampung Selatan ditemukan 22,9\% penderita pneumonia pada Balita.

Desa Muara Putih berada di Wilayah Kerja Puskesmas Tanjungsari Kecamatan Natar Kabupaten Lampung Selatan merupakan desa yang ditetapkan sebagai desa Open Defecation Free (ODF) sementara 629 KK belum memiliki jamban. Desa Muara Putih memiliki 6 dusun, yaitu Dusun Muara Putih Induk dengan kepemilikan jamban sebanyak 100\%, Mujimulyo (45,61\%), Tangkit Batu $(53,95 \%)$, Way Kandis $(57,39 \%)$, Cisarua $(63,47 \%)$ dan Sidomukti (57\%). Diantara 6 dusun tersebut tingkat kepemilikian jamban terendah adalah Dusun Mujimulyo, dari $171 \mathrm{KK}$ yang telah memiliki jamban sebanyak 45,61\%. Selama ini, warganya masih banyak yang melakukan pembuangan tinja dan air limbah domestik langsung ke dalam aliran air yang ada di desa tersebut. 
Desa Muara Putih berada di Wilayah Kerja Puskesmas Tanjungsari Kecamatan Natar Kabupaten Lampung Selatan merupakan desa yang ditetapkan sebagai desa ODF. Tingkat kepemilikian jamban terendah adalah Dusun Mujimulyo, dari $171 \mathrm{KK}$ yang telah memiliki jamban sebanyak $45,61 \%$. Selama ini, warganya masih banyak yang melakukan pembuangan tinja dan air limbah domestik langsung ke dalam aliran air yang ada di desa tersebut.

Melihat kondisi tersebut, dihawatirkan dapat berpengaruh pada semakin menurunnya kesehatan masyarakat. Ketersediaan sarana jamban yang sesuai syarat kesehatan diharapkan dapat mengurangi tingkat pencemaran air sungai dan meningkatkan kualitas lingkungan yang berimplikasi kepada peningkatan derajat kesehatan masyarakat. Berdasarkan pertimbangan di atas, maka dibutuhkan upaya pengolahan yang tepat dan optimal. Adanya bangunan WC dan tangki septik (septic tank) dalam skala sangat efektif untuk menurunkan tingkat pencemaran dan melindungi ekosistem perairan.

Kegiatan pengabdian kepada masyarakat ini bertujuan untuk meningkatkan derajat kesehatan masyarakat khususnya masyarakat di Dusun Mujimulyo Desa Muara Putih Kecamatan Natar Kabupaten Lampung Selatan melalui instalasi WC secara swadaya dan perubahan perilaku hidup bersih dan sehat melalui penyuluhan kesehatan. Manfaat yang dapat dirasakan dari kegiatan ini adalah meningkatnya derajat kesehatan masyarakat diakibatkan oleh perubahan perilaku yang awalnya Buang Air Besar (BAB) di sembarang tempat menjadi $\mathrm{BAB}$ di jamban yang telah terbangun.

\section{Bahan dan Metode}

Bahan yang digunakan untuk kegiatan intalasi WC adalah Semen, pasir, bata, koral, kasau, reng, seng. Alat yang digunakan cangkul, terpal cetakan septic tank, sendok semen, palu, dan paku. Metode yang akan digunakan dalam pelaksanaan kegiatan meliputi Penyampaian Surat Tugas Dosen Poltekkes Tanjungkarang untuk melaksanakan kegiatan pengabdian masyarakat kepada Kepala Puskesmas Tanjungsari dan Kepala Desa Muara Putih, dilanjutkan rapat koordinasi tim dosen, penyampaian proposal kegiatan, pertemuan tim dosen, petugas sanitarian Puskesmas Tanjungsari dan Kepala Desa Muara Putih dan dalam rangka persiapan tempat, materi, alat dan bahan yang digunakan. Selanjutnya melakukan instalasi WC dan penyuluhan kesehatan.

\section{Hasil dan Pembahasan}

Kegiatan pengabdian kepada masyarakat dilaksanakan pada bulan September sd. Desember 2017. Berdasarkan hasil kesepakatan, kegiatan yang dilaksanakan adalah melakukan kegiatan pemetaan, pemicuan kepada masyarakat, pembangunan sarana jamban, melakukan Penyuluhan pada tanggal 11, 12, 25 November dan 2 Desember 2017, tentang ISPA, Diare, CTPS dan Kecacingan. Kegiatan pembangunan dilaksanakan secara bersama-sama dengan masyarakat Dusun Mujimulyo Desa Muara Putih.

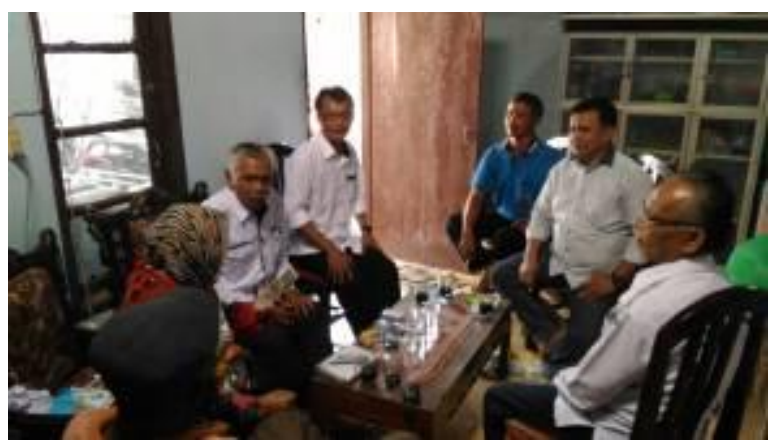

Gambar 1. Rapat koordinasi dosen, pejabat desa dan Puskesmas

Pada tahap persiapan, diadakan koordinasi antara dosen, kepala puskesmas, Kepala Desa dan petugas sanitarian Puskesmas pada tanggal $21 \mathrm{sd}$ 23 September 2017 di Desa Muara Putih untuk membangun kesepakatan tentang prioritas kegiatan yang akan dilaksanakan. Selanjutnya pada tahap pelaksanaan dilakukan juga rapat koordinasi antar dosen untuk memantapkan kegiatan dan memantau kesiapan materi dan sarana yang akan diberikan kepada masyarakat.

Tahapan berikutnya adalah pemetaan rumah warga yang belum memiliki sarana sanitasi dasar, dilaksanakan pada tanggal 19-21 Oktober 2017. Hasil pemetaan menyatakan bahwa dari 6 (enam) Dusun yang ada di Desa Muara Putih, tingkat kepemilikan jamban paling rendah pada Dusun Mujimulyo yaitu sebanyak 45,61\%.

Pada pemetaan yang telah dilakukan, masih terdapat $14,95 \%$ masyarakat memiliki PHBS yang kurang baik. 45,88\% mencuci tangan tidak menggunakan sabun. Dan sejumlah 57,73\% masyarakat memiliki pengetahuan kurang baik tentang penyakit kecacingan. Pengetahuan 
masyarakat tentang diare, tampak pada tabel berikut:

Tabel 1. Distribusi Pengetahuan Masyarakat tentang Diare di Desa Muara Putih Kecamatan Natar Kabupaten Lampung Selatan Tahun 2017

\begin{tabular}{lcc}
\hline \multicolumn{1}{c}{ Pengetahuan } & N & \% \\
\hline Baik & 167 & 86,08 \\
Kurang Baik & 27 & 13,92 \\
$\quad$ TOTAL & 194 & 100,00 \\
\hline
\end{tabular}

Dari tabel 1 dapat dijelaskan bahwa pengetahuan responden tentang diare, sebanyak $13,92 \%$ masih kurang baik, $86,08 \%$ sudah baik. Sedangkan pengetahuan masyarakat tentang penyakit ISPA masih banyak yang kurang yaitu sebesar $67,01 \%$

Setelah mendapatkan gambaran tentang penyakit, pengetahuan dan perilaku hidup bersih dan sehat, selanjutnya kegiatan diarahkan untuk pembangunan sarana dan penyuluhan. Sebelum pembangunan sarana, dilakukan pemicuan, memotivasi masyarakat dalam memperbaiki pola kehidupannya menjadi pola hidup sehat dengan STOP BAB sembarangan. Kegiatan ini dilaksanakan tanggal 26 Oktober 2017. Dengan adanya pemicuan ini target utama $d$ apat tercapai, yaitu merubah perilaku masyarakat berkaitan dengan sanitasi yang masih melakukan BAB disembarang tempat. Faktor-faktor yanng harus dipicu beserta metode yang digunakan dalam kegiatan STBM semata utnuk menghasilkan perubahan perilaku sanitasi dalam suatu komunitas $^{[4]}$.

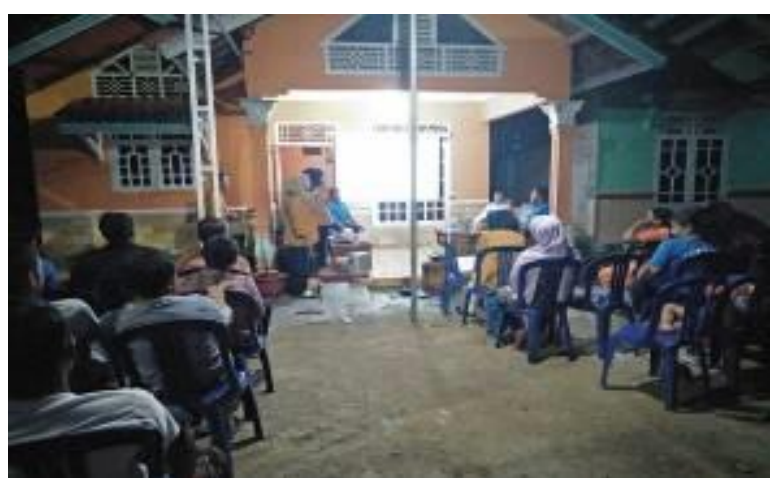

Gambar 2. Kegiatan Pemicuan masyarakat

Saat pemicuan, masyarakat termotivasi dan bersedia untuk membangun WC percontohan di rumahnya, selanjutnya masyarakat akan meneruskan kegiatan namun mengharapkan pendampingan dari dosen Jurusan Kesehatan Lingkungan, sehingga dapat mencapai desa ODF.

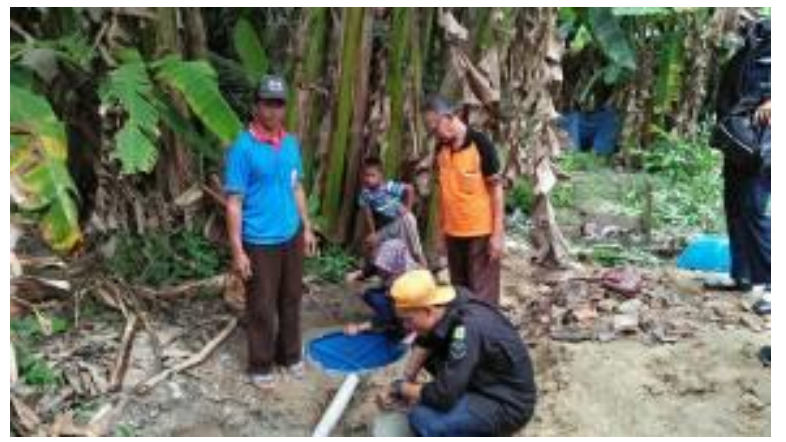

Gambar 3. Proses Instalasi WC (pembuatan lubang septictank)

Pembangunan sarana jamban 28 Oktober, 2,3,4,9,10,16,17,23 dan 24 November 2017 menghasilkan 5 jamban percontohan dibangun di rumah Ibu Rasti, Bapak Sutarno, Bapak Mulyono, Bapak Ponimin dan Bapak Rosikin.

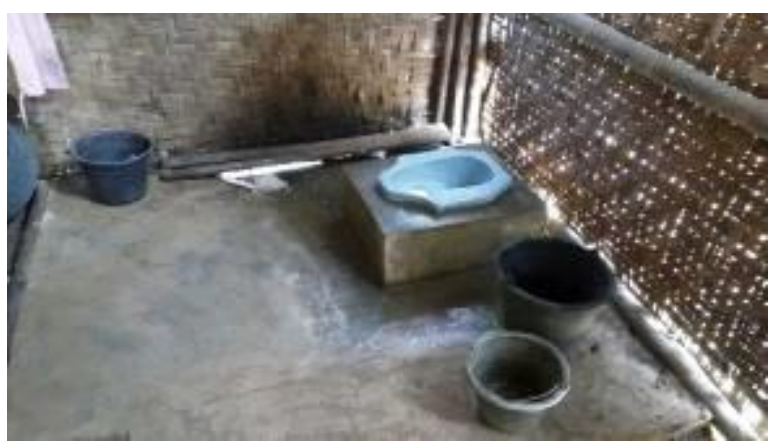

Gambar 4. Jamban percontohan terpasang

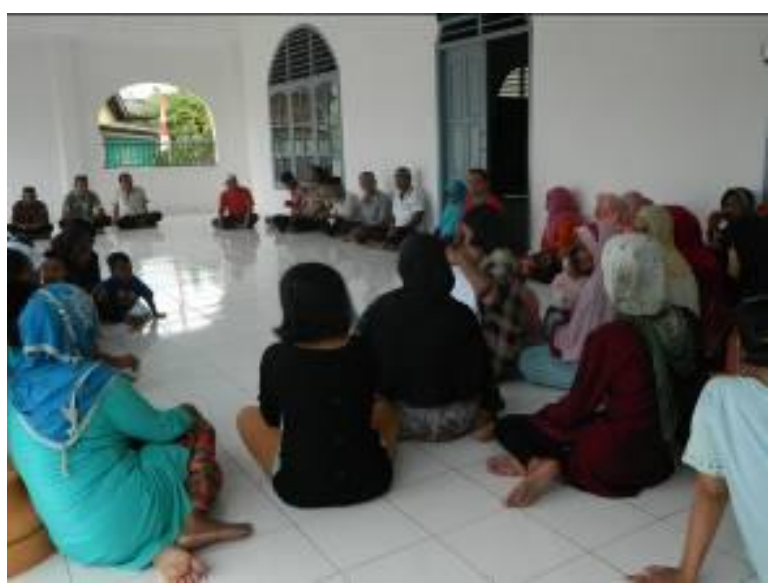

Gambar 5. Penyuluhan kesehatan

Penyuluhan kesehatan dilakukan sebanyak 4 kali, penyuluhan pertama tentang diare. Selama ini masyarakat masih menganggap bahwa terjadinya 
diare disebabkan oleh anak yang akan bertampah kepintarannya, sebagai tanda bahwa pertumbuhan gigi pada anak sudah dimulai, atau anak akan segera panai berjalan. Padahal anggapan seperti itu adalah anggapan yang salah. Kejadian diare tidak bisa dianggap remeh. Diare adalah masalah kesehatan yang harus segera diatasi. Karena jika tidak segera ditanggulangi dapat menimbulkan kematian. Untuk menghindari meluasnya diaera, dapat dilakukan upaya perilaku hidup bersih dan sehat antara lain membuang kotorang (tinja) di WC supaya tinja terisolasi dari serangga pembawa penyakit, selalu mencuci tangan dengan sabun (gerakan CTPS) setiap selesai melakukan pekerjaan, sebelum dan sesudah dan setelah menceboki anak.

Penyuluhan kedua tentang penyakit kecacingan. Makan dan minuman yang mengandung bakteri atau parasit dapat menjadi media penularan penyakit kecacingan, demikian pula kotoran manusia. Penyuluhan penyakit kecacingan memberikan informasi tentang pengertian, tanda dan gejala serta pencegahan yang dapat dilakukan di tingkat rumah tangga.

Penyuluhan berikutnya memaparkan tentang penyakit ISPA. Sama halnya dengan penyakit Diare, ISPA juga tidak dapat dianggap remeh karena penyakit saluran pernafasan ini bersifat akut dan kronis dan dapat mengakibatkan kematian. Penyuluhan terakhir tentang cuci tangan pakai sabun. Masyarakat diajak untuk memperagakan cuci tangan pakai sabun dan diharapkan bisa menularkan pengetahuan kepada anggota keluarganya sehingga dipraktikkan dalam kehidupan sehari-hari.

Evaluasi akhir dilakukan untuk mengetahui tingkat pemahaman masyarakat tentang materi yang telah disampaikan. Masyarakat telah memahami tentang penyakit diare, kecacingan dan ISPA, selain itu dapat mempraktikkan cuci tangan pakai sabun dengan benar.

Ketika masyarakat telah berada pada kondisi tidak BAB sembarangan, mencuci tangan pakai sabun, mengelola iar minum dan makanan dengan aman, mengelola sampah dengan benar, juga mengelola limbah rumah tangga dengan benar, maka itulah yang dinamakan dengan sanitasi total berbasis masyarakat menurut keputusan Menteri kesehatan Republik Indonesia No. 852/MENKES/SK/IX/2008 ${ }^{[5]}$.

\section{Kesimpulan}

Kegiatan pengabdian kepada masyarakat yang dilaksanakan di Desa Muara Putih Kecamatan Natar Kabupaten Lampung Selatan telah berjalan dengan lancar, kegiatan dilakukan dalam bentuk instalasi WC percontohan dan penyuluhan tentang ISPA, Diare, CTPS serta kecacingan. Untuk membantu masyarakat dalam hal kepemilikan jamban dan bisa menjadi Desa ODF, kegiatan pengabdian masyarakat dapat dilanjutkan oleh Himpunan Mahasiswa Jurusan. Rencana kegiatan pengabdian masyarakat bidang kesehatan disusun dengan mengacu pada kebutuhan masyarakat untuk meningkatkan lingkungan yang sehat dalam mencapai tujuan hidup sehat.

\section{Ucapan Terima Kasih}

Terima kasih kami sampaikan kepada Himpunan Mahasiswa Program Studi Diploma IV Kesehatan Lingkungan Politeknik Kesehatan Tanjungkarang yang telah membantu pelaksanaan kegiatan sehingga dapat berjalan dengan lancar.

\section{Daftar Pustaka}

WSP (Water and Sanitation Program), 2008. Manual pelaksanaan Program Sanitasi Total \& Pemasaran Sanitasi (SToPS).

Pusdatin Kemenkes RI, 2015. Profil Kesehatan Indonesia Tahun 2015, Kementrian Kesehatan RI, Jakarta.

Dinas Kesehatan Kabupaten Lampung Selatan, 2017. Profil Kesehatan Kab. Lampung Selatan Tahun 2016. Kalianda.

Depkes RI, 2008. Strategi Nasional Sanitasi Total berbasis Masyarakat. Jakarta.

Kemenkes RI, 2008. Keputusan Menteri Kesehatan Republik Indonesia No. 852/MENKES/SK/IX/2008 tentang Sanitasi Total Berbasis Masyarakat. 